\title{
Uso de Animais em Rituais Religiosos e Legislação Brasileira em Vigor
}

Gislane Junqueira Brandão*

Exposição de motivos: o presente trabalho visa resolver definitivamente qualquer dúvida quanto à existência de crime no uso de animais, com maus-tratos, em rituais religiosos, de forma a deixar clara a incidência, nestes casos, do artigo 32 da Lei $n^{\circ}$ 9.605/98, chamada Lei de Crimes Ambientais, demonstrando que, efetivamente, a liberdade traduzida no artigo $5^{\circ}$, inciso VI, da Constituição Federal não tem o condão de funcionar como excludente de antijuridicidade.

\section{DA CONSTITUIÇÃO DA REPÚBLICA FEDERATIVA DO BRASIL.}

Em 05 de outubro de 1988, foi promulgada a Constituição da República Federativa do Brasil, documento que rege todo o atual sistema jurídico do país, ou seja: nenhuma norma pode contrariar seus ditames. Qualquer tese, fundamento jurídico etc deverá estar em plena concordância com o texto constitucional para que tenha validade. Esta

\footnotetext{
Advogada em Salvador (BA). Diretora da ong União Defensora dos Animais Bicho Feliz e membro do Instituto Abolicionista Animal.
} 
imperatividade constitucional age de tal forma que a própria existência do cidadão brasileiro a ela se subordina e nela tem seus limites claramente determinados.

A Constituição de 1988, considerada moderna e avançada, trouxe em seu texto dispositivos quanto a tutela ambiental, sacramentando a proteção constitucional ao meio ambiente, destinando todo um capítulo sobre o tema.

\section{DO ARTIGO 225 DA CONSTITUIÇÃO DE 1988}

Em seu rol de normas e comandos, a Constituição Federal, em seu Título VIII, denominado “Da Ordem Social”, Capítulo VI, art. 225, tratando do meio ambiente, dispôs:

"Art. 225. Todos têm direito ao meio ambiente ecologicamente equilibrado, bem de uso comum do povo e essencial à sadia qualidade de vida, impondo-se ao Poder Público e à coletividade o dever de defendê-lo e preservá- lo para as presentes e futuras gerações.

$\S 1^{\circ}$ - Para assegurar a efetividade desse direito, incumbe ao Poder Público:

I - preservar e restaurar os processos ecológicos essenciais e prover o manejo ecológico das espécies e ecossistemas;

II - preservar a diversidade e a integridade do patrimônio genético do País e fiscalizar as entidades dedicadas à pesquisa e manipulação de material genético;

III - definir, em todas as unidades da Federação, espaços territoriais e seus componentes a serem especialmente protegidos, sendo a alteração e a supressão permitidas somente através de lei, vedada qualquer utilização que comprometa a integridade dos atributos que justifiquem sua proteção;

IV - exigir, na forma da lei, para instalação de obra ou atividade potencialmente causadora de significativa degradação do meio ambiente, estudo prévio de impacto ambiental, a que se dará publicidade; 
V - controlar a produção, a comercialização e o emprego de técnicas, métodos e substâncias que comportem risco para a vida, a qualidade de vida e o meio ambiente;

VI - promover a educação ambiental em todos os níveis de ensino e a conscientização pública para a preservação do meio ambiente; VII - proteger a fauna e a flora, vedadas, na forma da lei, as práticas que coloquem em risco sua função ecológica, provoquem a extinção de espécies ou submetam os animais a crueldade.

$\S 2^{\circ}$ - Aquele que explorar recursos minerais fica obrigado a recuperar o meio ambiente degradado, de acordo com solução técnica exigida pelo órgão público competente, na forma da lei. $\S 3^{\circ}$ - As condutas e atividades consideradas lesivas ao meio ambiente sujeitarão os infratores, pessoas físicas ou jurídicas, a sanções penais e administrativas, independentemente da obrigação de reparar os danos causados.

$\S 4^{\circ}$ - A Floresta Amazônica brasileira, a Mata Atlântica, a Serra do Mar, o Pantanal Mato-Grossense e a Zona Costeira são patrimônio nacional, e sua utilização far-se-á, na forma da lei, dentro de condições que assegurem a preservação do meio ambiente, inclusive quanto ao uso dos recursos naturais.

$\S 5^{\circ}$ - São indisponíveis as terras devolutas ou arrecadadas pelos Estados, por ações discriminatórias, necessárias à proteção dos ecossistemas naturais.

$\S 6^{\circ}$ - As usinas que operem com reator nuclear deverão ter sua localização definida em lei federal, sem o que não poderão ser instaladas.

Ficou claro, então, o desejo do legislador quanto a proteção ambiental.

\section{A CONSTITUIÇÃO DE 1988 E A FAUNA.}

O texto constitucional, acima transcrito, é expresso no tocante a proteção aos animais. O inciso VII do mencionado artigo determina como obrigação do Poder Público "Proteger a fauna e a flora, vedadas, na forma da lei, as práticas que coloquem em risco sua função ecológica, provoquem a extinção de espécies ou submetam os animais a crueldade". 


\section{DA CHAMADA LEI DE CRIMES AMBIENTAIS : LEI $\mathrm{N}^{\circ} 9605 / 98$}

Em 1998, norteado pela própria Constituição Federal, tratou o legislador de elaborar lei que tratasse dos crimes contra a fauna e a flora, rezando o citado artigo 32 do tratado diploma legal que:

"Praticar ato de abuso, maus-tratos, ferir ou mutilar animais silvestres, domésticos, domesticados, nativos ou exóticos:

Pena - detenção de três meses a um ano, e multa"

Assim foi que $\mathrm{o}$ ato de maltratar animais foi tipificado como crime.

\section{DA FAUNA E DOS RITUAIS RELIGIOSOS}

Lamentavelmente, apesar de toda proteção constitucional, apesar da Lei de Crimes ambientais, ouve-se falar do uso com sofrimento de animais em vários rituais religiosos, onde os animais são utilizados de forma violenta, são maltratados, abusados, desrespeitados e, geralmente, mortos.

Alguém na face da Terra pode negar a profunda dor por que passa, por exemplo, um animal ao ser esfaqueado?

Pois bem, tais atos que geram maus-tratos aos animais em rituais religiosos são criminosos, tipificados no art.32 da Lei $n^{\circ} 9.605 / 98$, a Lei de Crimes Ambientais.

\section{O ARTIGO $5^{\circ}$, INCISO VI DA CONSTITUIÇÃO FEDERAL E O CRIME DE MAUS-TRATOS AOS ANIMAIS.}

Como dito, apesar da legislação em contrário, alguns segmentos continuam praticando o bárbaro crime contra os animais que é seu uso com sofrimento nos tratados rituais. Para tanto, muitas vezes, lançam mão do art. $5^{\circ}$, inciso VI da Constituição Federal que diz o seguinte: 
“É inviolável a liberdade de consciência e de crença, sendo assegurado o livre exercício dos cultos religiosos e garantida, na forma da lei, a proteção aos locais de culto e suas liturgias".

Vale aí a análise minuciosa do artigo, aprofundando a leitura constitucional: Marcada pelo fato de ser a primeira Constituição Democrática, promulgada após longo período de Ditadura, teve o constituinte da época a responsabilidade de elaborar um texto cuja marca fosse a liberdade, liberdade de pensamento, de existir, de possuir, de manifestação, era um brinde a nova era do país. Assim, uma das preocupações do legislador era a liberdade religiosa, crer no que se acredita, direito a freqüentar o culto que se queira, de forma livre, em compasso mais do que nunca com a euforia existente, na época, pela promulgação da referida Constituição.

Com este espírito, nasceu o referido inciso VI. Obviamente, o constituinte sacramentou o direito a liberdade de consciência e de crença: é a liberdade do pensamento. O cidadão é livre para crer. É o direito de crença. Mais do que isto, o constituinte consagrou a liberdade religiosa. O Estado não escolherá a crença do cidadão, sua religião, não proibirá os cultos religiosos de forma tão verdadeira que protegerá os locais de culto e suas liturgias.

É isto que diz o inciso em questão: Liberdade de consciência e de crença em oposição à opressão e liberdade de exercício de cultos religiosos em oposição à proibição de sua existência ou até em oposição à adoção pelo Estado de religião oficial.

Tal liberdade, obviamente, tem limitações. Jamais, em tempo algum, o constituinte criou uma anarquia legislativa de forma que em nome de uma religião tudo fosse possível: cometer crimes, ilícitos etc. Ou seja: ninguém pode cometer um ilícito, um crime e não ser punido por estes atos em virtude da alegação de "estar no gozo de sua liberdade religiosa".

O STF - Supremo Tribunal Federal - já se pronunciou quanto a questão relacionada aos limites constitucionais:

"As liberdades públicas não são incondicionais, por isso devem ser exercidas de maneira harmônica, observados os limites definidos na própria Constituição Federal $\left(\mathrm{CF}\right.$, artigo $5^{\circ}$, $\$ 2^{\circ}$, primeira 
parte). O preceito fundamental de liberdade de expressão não consagra o direito à incitação ao racismo, dado que um direito individual não pode constituir-se em salvaguarda de condutas ilícitas, como sucede com os delitos contra a honra. Prevalência dos princípios da dignidade da pessoa humana e da igualdade jurídica" (HC 82.424, Rel. Min. Maurício Corrêa, DJ 19.03.04).

\section{DO PRINCÍPIO DA PROPORCIONALIDADE}

A Constituição de 1988 foi concebida sob o claro esteio de valores éticos, buscando sempre a valorização da vida. Assim, objetivando-se a melhor aplicação da norma constitucional, deve-se buscar o menor dano possível aos valores éticos, consagrando-se a vida como fator determinante das escolhas, fazendo-se o uso do já consagrado Princípio da Proporcionalidade.

"O princípio da proporcionalidade é aquele que orienta o intérprete na busca da justa medida de cada instituto jurídico. Objetiva a ponderação entre os meios utilizados e os fins perseguidos" (Curso de Direito Constitucional, Luis Alberto David Araújo e Vidal Serrano Junior, $10^{\mathrm{a}}$ Edição).

\section{DO ARTIGO $5^{\circ}$, INCISO VI, DA CONSTITUIÇÃO FEDERAL, DO CRIME E DA NÃO EXCLUSÃO DA ILICITUDE.}

Para ser considerado crime, o fato deve ser típico e antijurídico, ou seja, além de estar taxado na norma penal como crime, deverá sofrer a antijuridicidade.

"A antijuridicidade, segundo requisito do crime, pode ser afastada por determinadas causas, denominadas "causas de exclusão da antijuridicidade" ou "justificativas". Quando isso ocorre, o fato permanece típico, mas não há crime: excluindo-se a ilicitude, e sendo ela requisito 
do crime, fica excluído o próprio delito. Em conseqüência, o sujeito deve ser absolvido. São causas de exclusão da antijuridicidade, previstas no art.23 do CP: $1^{\circ}$ ) estado de necessidade; $2^{\text {a) }}$ legítima defesa, $3^{\mathrm{a}}$ ) estrito cumprimento de dever lega; $4^{\mathrm{a}}$ )exercício regular de direito" (Direito Penal, Damásio de Jesus, $1^{\circ}$ Volume-Parte Geral, $22^{\text {a }}$ Edição)

Assim, não resta dúvida de que o cidadão em nome da religião não pode praticar condutas contrárias às leis, à própria Constituição. $\mathrm{O}$ artigo $5^{\circ}$, inciso VI, da Constituição Federal não funciona como excludente de ilicitude. Não resta dúvida que o uso com sofrimento de animais em rituais religiosos é proibido e mais do que proibido é crime tipificado pela Lei de Crimes Ambientais, proibido pela Constituição Federal que repele maus-tratos aos animais.

Vale repetir o texto constitucional:

"Proteger a fauna e a flora, vedadas, na forma da lei, as práticas que coloquem em risco sua função ecológica, provoquem a extinção de espécies ou submetam os animais a crueldade"

É transparente que a norma constitucional consagrou o direito à vida, o respeito aos animais, proibiu as práticas que submetam os animais à crueldade.

Assim, maltratar animais é crime. Não podendo o criminoso valerse do tratado inciso VI como causa de exclusão de ilicitude.

\section{DO PRINCÍPIO DA IGUALDADE}

Por analogia, se assim não fosse, quem matasse alguém em um ritual em nome da liberdade da prática religiosa não estaria cometendo o crime de homicídio. O Estado estaria criando uma situação anômala onde todo ato seria permitido, não sendo considerado crime sempre que houvesse a alegação da incidência do artigo $5^{\circ}$, VI da constituição Federal. Estaríamos diante de uma verdadeira aberração jurídica.

Consideremos a situação A e a situação B: Na situação A, a título de liberdade religiosa, alguém utilizou um animal em ritual religioso causando-lhe sofrimento, na situação B alguém utilizou uma criança em ritual religioso semelhante causando-lhe sofrimento. Na situação B a Justiça Brasileira condenou o autor do fato, considerando o fato 
noticiado como crime, e no caso A não condenou. É possível tal hipótese estar coberta de legalidade? Claro que não. Nos dois casos há crime, não podendo em um dos casos ser considerada a liberdade religiosa como excludente de ilicitude e no outro não, pois, se isto ocorrer, o Julgador estará atentando contra o Princípio Constitucional da Igualdade, já que "todos os cidadãos têm o direito de tratamento idêntico pela lei” (Direito Constitucional, Alexandre de Moraes, $6^{\text {a Edição) }}$

A própria Constituição Federal trouxe no seu bojo a seguinte norma:

"Ninguém poderá invocar crença religiosa para eximir-se de obrigação legal a todos imposta" (CF, art. $5^{\circ}$, VIII)

\section{DA AÇÃO PENAL PÚBLICA INCONDICIONADA E DOS CRIME DO ARTIGO 32 DA LEI 9605/98}

Por tudo que foi exposto, fica claro a incidência do artigo 32 da Lei ${ }^{\circ} 9.605 / 98$, Lei de Crimes Ambientais, nos casos de uso de animais com sofrimento em rituais religiosos.

Deve-se salientar que o crime tipificado no artigo 32 da referida lei é crime de ação penal pública incondicionada, cabendo ao Ministério Público promover a ação penal toda vez que estiver diante do uso com sofrimento de animais em rituais religiosos. Tal crime norteia-se pelos seguintes princípios: Princípio da Obrigatoriedade; Princípio da Oficiosidade; Princípio da Indisponibilidade; Princípio da Oficialidade; Princípio da Autoritariedade; Princípio da Indivisibilidade e Princípio da Intranscedência.

Dos Princípios citados, dois merecem destaque:

Princípio da Obrigatoriedade: "Identificada a hipótese de atuação, não pode o Ministério Público recusar-se a dar início à ação penal” (Curso de Processo Penal, Fernando Capez, $5^{\text {a Edição) }}$

Princípio da Oficiosidade: "Os encarregados da persecução penal devem agir de ofício, independentemente de provocação" ( Curso de Processo Penal, Fernando Capez, $5^{\text {a }}$ Edição) 


\section{CONCLUSÃO}

Conclui-se, portanto, que a utilização de animais em rituais religiosos, com as práticas tratadas no artigo 32 da Lei de Crime Ambientais é crime. Não servindo o artigo $5^{\mathrm{a}}$, VI, da Constituição Federal como excludente de antijuridicidade. Atendendo-se assim a valorização constitucional da vida e da ética. 